\title{
O planejamento nacional da política de saúde no Brasil: estratégias e instrumentos nos anos 2000
}

\author{
National planning of health policy in Brazil: \\ strategies and instruments in the 2000s
}

Cristiani Vieira $\mathrm{M} \mathrm{achado}^{1}$

Tatiana Wargas deFaria Baptista ${ }^{1}$

Luciana Dias de Lima ${ }^{1}$

\footnotetext{
${ }^{1}$ Departamento de Administração e Planejamento em Saúde Escola N acional deSaúde Pública Sergio Arouca, Fundação Oswaldo Cruz. Rua Leopoldo Bulhões $1.480 / 715$, M anguinhos, 21041-210 Rio deJaneiro RJ. cristiani@ensp.fiocruz.br
}

Abstract This paper discusses thenational planning of health policy between 2003 and 2010, in the light of the development of state planning in Brazil and Lula's administration. Firstly an historical overview is presented of the key moments for national planning, regarding its effects on health care. The governmental context is then described with a review of the strategies and instruments in health planning over recent years. The methodology involved a bibliographic and documental review - including the M ulti-year Plans, the $\mathrm{N}$ ational $\mathrm{H}$ ealth Plan, the $\mathrm{H}$ ealth Pact and the $\mathrm{M}$ ore $\mathrm{H}$ ealth program - considering their intention, contents and development processes. The results indicate that national health planning has been condensed in order to enable better direction of the policy. Two key moments in federal health planning wereidentified: between 2003 and 2006 a managerial and participativelinewas followed; between 2007 and 2010, the managerial linewaskept allied to an effort to tie health policy to the development model. Despite the advances, health planning has displayed limitations, such as: restrictions in health financing, which has compromised the execution of the plans; failure to tackle structural problems in the health care system; and the fragile territorial organization. Key words Planning in health care, National planning, Health policy, M inistry of $\mathrm{H}$ ealth
Resumo 0 artigo enfoca o planejamento nacional da política de saúde de 2003 a 2010, à luz da trajetória do planejamento estatal no Brasil e do contexto do Governo Lula. Inicialmente, étraçado um histórico dos momentos relevantes para 0 planejamento nacional, considerando suas interfaces com a saúde. A seguir, situa-se o contexto governamental e discutem-se as estratégias e instrumentos de planejamento em saúde recentes. A metodologia envolveu revisão bibliográfica eanálise de documentos - os planos plurianuais, o Plano Nacional de Saúde, o Pacto pela Saúde e o M ais Saúde - considerando o seu propósito, conteúdo e processo de elaboração. Os resultados sugerem um adensamento do planejamento nacional em saúde, visando dar direcionalidadeà política. Foram identificados dois momentos no planejamento federal em saúde: entre 2003 e 2006, predominou uma orientação participativa e ge rencialista; entre 2007 e 2010, a orientação gerencialista semantevee houveum esforço deatrelar a política de saúde ao modelo de desenvolvimento. A pesar dos avanços, o planejamento em saúde expressou limitações como a não regulamentação do financiamento setorial, que tem comprometido a execução dos planos, o escasso enfrentamento de problemas estruturais do sistema de saúde e a fragilidade da lógica territorial.

Palavras-chave Planejamento em saúde, Planejamento nacional, Política de saúde, M inistério da Saúde 
Introdução

0 debate sobre o planejamento estatal tem sido tratado sob diferentes enfoques, nos diversos campos de conhecimento eáreas da política. Este artigo enfoca o planejamento nacional da política de saúde no Brasil de 2003 a 2010. Além da caracterização das estratégias e instrumentos de planejamento adotados pelo M inistério da Saúde, busca-se analisar o planejamento nacional da saúde à luz da trajetória do planejamento estatal no Brasil e do contexto do Governo Lula.

A análise do planejamento setorial no período de um governo específico encerra desafios metodológicos, relacionados ao cotejamento das perspectivas: teórica e histórica; estrutural econjuntural; nacional efederativa; geral esetorial; estatal egovernamental; técnica e política. Na interface dessas perspectivas é que se situam as pontes analíticas para explicar os avanços e limites do planejamento em saúde em um dado contexto.

Dada a complexidade do tema, cabe explicitar os pontos de partida do estudo. 0 primeiro é 0 reconhecimento de que o planejamento estatal esteve, em suas origens, associado à expansão das funções do Estado na defesa eeconomia. No século XX, em vários países, houve aumento do intervencionismo estatal por meio do planejamento e produção direta de serviços nas áreas econômica e social. Esse movimento envolveu, em geral, a conformação de órgãos e quadros de servidores.

0 segundo ponto é que a expansão do plane jamento estatal ocorreu deforma diferenciadanas regiões e países. Na América Latina, o debate eas experiências de planejamento nacional estiveram associados à questão do desenvolvimento ${ }^{1,2}$. 0 planejamento era considerado o instrumento para superar os problemas relacionados à inserção diferenciada dos países latino-americanos no sistema mundial eàs condições precárias de desenvolvimento. 0 maior status do planejamento é observado nos anos cinquenta esessenta, relacionado à atuação da Comissão Econômica para a América Latina (CEPAL) e ao auge das ideias desenvolvimentistas, ainda que experiências deplanejamento já fossem observadas anteriormente.

Porém, os avanços no planejamento em países da região - formação de burocracias especializadas, elaboração de planos - nem sempre coincidiram com mudanças estruturais. Em algumas situações, somente representaram esforços de compreensão da realidade latino-americana e de suas perspectivas, nos âmbitos técnico eintelectual ${ }^{1}$.
A crítica ao planejamento normativo e restrito às tecnoburocracias deu origem ao enfoque estratégico de planejamento, que val oriza o diagnóstico ou a análise situacional como ponto de partida para o planejamento, o planejamento como um processo social e político amplo e o plano como um instrumento de aposta para o futuro ${ }^{2}$.

A adoção da perspectiva estratégica na Amé rica Latina foi limitada, visto que, em muitos países, o fortalecimento do planejamento nacional ocorreu sob regimes autoritários, associado à centralização política efinanceira. Ainda assim, alguns apresentaram avanços na construção das bases para o planejamento e alcançaram resultados pontuais.

A partir do final dos anos setenta, as transformações mundiais e o fortalecimento das ideias neoliberais levaram ao questionamento eà crise do Estado interventor ${ }^{3}$, gerando uma crise do planejamento nacional. Após duas décadas de reformas, sobram evidências de que os Estados desempenham um papel fundamental na sustentação do capitalismo eque as políticas adotadas pelos governos têm relevância para a sua inserção no cenário mundial ${ }^{4}$. N esse contexto, a retomada da discussão sobre a capacidade do Estado e o planejamento nacional é essencial.

Os movimentos relativos ao planejamento estatal repercutem de forma diferenciada entre as políticas sociais, pois tais políticas não são determinadas apenas pela sua inserção estrutural no Estado capitalista. Para a compreensão das funções, organização e estratégias do Estado na área social, énecessário considerar as peculiaridades das políticas sociais que as distinguem nos processos históricos das sociedades 5 .

A trajetória do planejamento em saúde na América Latina, no âmbito teórico e prático, re fletiu o cenário geral, a singularidade da saúde como campo de interven ção estatal ${ }^{2}$ eas especificidades dos sistemas de saúde dos países.

O Brasil, no século XX, apresentou momentos de fortalecimento e crise do planejamento, com expressões na saúde. Nas últimas décadas, observam-se transformações no modelo de intervenção do Estado e nas políticas setoriais. N esse sentido, é pertinente a real ização de estudos sobreo planejamento nacional em saúdeque busquem contribuir para a compreensão das relações entre a ação estatal e as mudanças na política, o que constitui o propósito destetrabalho. 


\section{M etodologia}

A pesquisa valorizou a influência da trajetória histórica nos desdobramentos das políticas, 0 peso das regras que regem a atuação do Estado e a importância dos atores nas políticas públicas, ainda quesuas escol has sejam condicionadas por limites estruturais e institucionais $5^{6,7}$.

Foram privilegiadas como categorias de análise a trajetória do planejamento estatal no Brasil, o contexto do Governo Lula, as estratégias e os instrumentos federais de planejamento em saúde de 2003 a 2010. As estratégias de planejamento foram compreendidas como os processos sob condução do M inistério da Saúde relacionados à afirmação deseu papel planejador na política, incluindo a articulação com outros setores eesferas de governo. Já os instrumentos são os dispositivos que materializam a ação planejadora federal, como os planos e pactos formais.

As estratégias metodológicas foram a revisão bibliográfica e a análise documental, com destaque para os planos plurianuais, o Plano Nacional de Saúde, o Pacto pela Saúde e o M ais Saúde. $\mathrm{Na}$ análise desses instrumentos, foram consideradas as variáveis propósito, forma/conteúdo e processo de elaboração.

Notas sobre a trajetória do planejamento nacional no Brasil esuas interfaces com a saúde

Apesar de suas origens serem anteriores, a evolução do planejamento estatal no Brasil esteve, no campo das ideias e das práticas, associada à questão do desenvolvimento e ao fomento da industrialização. Em vários momentos da história da República, observa-sea existência de uma política deliberada que expressou a conversão das ideias em um guia de ação $0^{8,9}$.

A trajetória do planejamento estatal nacional sugere como momentos principais: (a) 1889-1929 - origens do planejamento; (b) 1930-1945 - estruturação das bases para o planejamento; (b) 1950-1963 - planejamento desenvolvimentista; (c) 1964-1979 - planejamento autoritário; (d) 1980-1994- crise do planejamento; (e) 1995-2002 - planejamento gerencialista.

Desdea Primeira República, o positivismo influenciou a difusão das ideias de uma intervenção estatal planejada com o propósito de construção do futuro ${ }^{8}$. A política dedefesa do cafée da indústria foram peças-chave da modernização ${ }^{10}$. A saúde era uma questão prioritária para o Estado, dentro deum "projeto civilizatório", queenvolveu a reorganização dos espaços urbanos e rurais e 0 controle de endemias e epidemias ${ }^{11}$.

Entre 1930 e 1945, no primeiro Governo Vargas, foram montadas as bases de ampliação e racionalização da intervenção do Estado, em geral sob um regime autoritário, com centralização federal e ruptura do pacto federativo anterior. Houve uma reforma administrativa, com criação de novos órgãos e adoção de normas de profissionalização do serviço público, influenciada pelas teorias da administração científica epela noção weberiana de burocracia ${ }^{12}$.

As reformas também expressaram orientações relativas às atividades-fim do Estado, tendo sido criadas instituições-chave para o desenvolvimento econômico. $\mathrm{Na}$ área social, destacaramse a expansão da legislação trabalhista ea criação em 1930 dos ministérios do Trabalho, Indústria e Comércio e da Educação eSaúdePública, inaugurando a trajetória dual da política de saúde ${ }^{11}$. Osinstrumentos de planejamento nacional eram fragmentados e os planos se dirigiram para a área de infraestrutura.

O terceiro momento (1950 a 1963) serelacionou ao auge do desenvolvimentismo, em um contexto democrático. No campo das ideias, as principais correntes desenvolvimentistas destacavam a importância do planejamento estatal ${ }^{9}$. Nos governos Vargas e Kubitschek, foram criadas estruturas estatais e implantadas estratégias econômicas relevantes, com mecanismos de "insulamento burocrático" na administração públi$\mathrm{Ca}^{13}$. Destaque-se a criação do cargo de M inistro Extraordinário dePlanejamento em 1962 ea elaboração de planos de desenvolvimento com ênfase na área econômica e de infraestrutura, embora alguns abordassem setores sociais.

H ouve inovações na saúde, com expansão da intervenção do Estado na vertente previdenciária sob um padrão seletivo, heterogêneo, centralizado e fragmentado ${ }^{14}$. $\mathrm{N}$ a vertente da saúde pública, foi criado o M inistério da Saúde em 1953, mantendo o foco no coletivo e nas doenças específicas $^{15}$. Ressalte-se a atuação dos sanitaristasdesenvolvimentistas, com a defesa de uma política de desenvolvimento includente e articulada a um planejamento nacional de saúde, como expresso na III Conferência Nacional de Saúde em $1963^{16}$.

O quarto momento corresponde ao período militar (1964-1979), quando foi conduzida uma estratégia de desenvolvimentismo autoritário associada às ideias de segurança nacional e do "Brasil potência" ${ }^{17}$. Na esfera econômica, houve 
expansão do intervencionismo estatal por meio do planejamento, financiamento eprodução por empresas estatais. No âmbito institucional, ressalte-se a reforma administrativa de 1967, com criação de novas formas jurídicas, a expansão das atribuições do órgão federal de planejamento e a criação do Instituto de Pesquisa Econômica A plicada ${ }^{18}$. Elaboraram-se grandes planos de desenvolvimento, sendo que alguns incluíam propostas para a saúde ${ }^{19}$.

A política de saúde expressou os traços gerais do sistema de proteção social em expansão centralização, fragmentação institucional, privatização ${ }^{14}$ - , sendo reiterada a divisão entreas vertentes previdenciária ede saúde pública. A inexistência de uma política de saúdeunificada dificultava a afirmação de um planejamento nacional de saúde. As estratégias einstrumentos de planejamento sugeriam uma direcionalidade da política adversa à perspectiva do direito, ainda que tenha havido iniciativas de expansão do acesso no âmbito previdenciário e em programas espe cíficos do M inistério da Saúde.

Um quinto momento éa crisedo planejamento (1980-1994) relacionada à crise do Estado, ao questionamento do seu papel interventor eàs re formas neoliberais. Os planos de desenvolvimento deram lugar aos de estabilização monetária. A década denoventa foi marcada pela democratização eliberalização econômica ${ }^{20}$. 0 questionamento do Estado interventor ea ênfasena descentralização e nas privatizações não favoreceram o planejamento nacional integrado e de longo prazo.

Ainda assim, a partir de 1995, configura-seum sexto momento, em que a implantação dos planos plurianuais (PPA) - propostos pela Consti- tuição de 1988 - traduz a tentativa de aproximação entre planejamento de médio prazo e orçamento federal, retoma conceitos do enfoqueestratégico, expressa a influência do planejamento corporativo e a expansão das práticas gerenciais. 0 núcleo do planejamento passa a ser a definição explícita deobjetivos para incidir em problemas selecionados, com tradução das políticas públicas em programas, projetos, indicadores e metas ${ }^{21}$. Ao final da década, observam-se iniciativas de planejamento mais consistentes, bem como a configuração de um "novo intervencionismo regulatório" 22 .

No âmbito da saúde, após o reconhecimento constitucional da saúde como direito, a implantação inicial do SistemaÚ nico deSaúdesedeu em um contexto desfavorável à expansão de políticas sociais universalistas. A condução nacional da política de saúde foi unificada no M inistério da Saúde, cujo modelo de intervenção expressou uma fragilidade do planejamento integrado e a preponderância de estratégias de curto prazo. A pesar de os planos serem previstos nas leis da saúde como instrumentos de gestão das três esferas de governo, durante os anos noventa, o M inistério da Saúde não elaborou um plano nacional desaúde queexplicitasseo diagnóstico situacional, diretrizes, prioridades e recursos de forma abrangente. Predominaram projetos por áreas específicas e iniciativas pontuais de coordenação intergovernamental, com base em prioridades ou metas acordadas. Em face da intensidade da descentralização, observou-se a ênfase na regulação dos sistemas estaduais emunicipais, por meio de normas e portarias federai $s^{23}$.

0 Quadro 1 resume os momentos históricos relevantes para o planejamento estatal no Brasil e suas interfaces com a saúde.

Quadro 1. Trajetória do planejamento estatal no Brasil e interfaces com a saúde no período de 1889 a 2002.

\begin{tabular}{|l|l|l|l|l|l|}
\hline \multicolumn{1}{|c|}{$\begin{array}{c}\text { Momentos } \\
\text { relevantes }\end{array}$} & $\begin{array}{c}\text { Contexto político } \\
\text { nacional }\end{array}$ & $\begin{array}{c}\text { Modelo de } \\
\text { desenvolvimento/ } \\
\text { política econômica }\end{array}$ & $\begin{array}{c}\text { Principais } \\
\text { instrumentos de } \\
\text { planejamento } \\
\text { estatal }\end{array}$ & $\begin{array}{c}\text { Sistema de } \\
\text { proteção social }\end{array}$ & $\begin{array}{c}\text { Marcos e } \\
\text { iniciativas da } \\
\text { saúde }\end{array}$ \\
\hline $\begin{array}{l}\text { 1889-1929 } \\
\text { Origens } \\
\text { do planejamento }\end{array}$ & $\begin{array}{l}\text { Primeira } \\
\text { República: projeto } \\
\text { civilizatório e } \\
\text { construção do } \\
\text { Estado; peso } \\
\text { militar; influência } \\
\text { do positivismo; } \\
\text { repressão. }\end{array}$ & $\begin{array}{l}\text { - Liberalismo } \\
\text { excludente; } \\
\text { - "Ordem e } \\
\text { progresso"; } \\
\text { - Política de defesa } \\
\text { do café; } \\
\text { - Início da } \\
\text { industrialização; } \\
\text { - Modernização } \\
\text { autoritária. }\end{array}$ & $\begin{array}{l}\text { - Sem registro de } \\
\text { planos integrados. }\end{array}$ & $\begin{array}{l}\text { - Organização } \\
\text { de Aposentadorias de Caixas } \\
\text { e Pensões } \\
\text { - Lei Eloy Chaves }\end{array}$ & $\begin{array}{l}\text { Higienismo e } \\
\text { movimento } \\
\text { sanitarista - } \\
\text { institucionalização } \\
\text { das ações de Saúde } \\
\text { Pública; reforma } \\
\text { urbana, } \\
\text { saneamento rural } \\
\text { e controle de } \\
\text { doenças. }\end{array}$ \\
\hline
\end{tabular}




\begin{tabular}{|c|c|c|c|c|c|}
\hline \multicolumn{6}{|c|}{ Quadro 1. continuação } \\
\hline $\begin{array}{l}\text { Momentos } \\
\text { relevantes }\end{array}$ & $\begin{array}{l}\text { Contexto } \\
\text { político } \\
\text { nacional }\end{array}$ & $\begin{array}{c}\text { Modelo de } \\
\text { desenvolvimento/ } \\
\text { política econômica }\end{array}$ & $\begin{array}{l}\text { Principais instrumentos } \\
\text { de planejamento estatal }\end{array}$ & $\begin{array}{c}\text { Sistema de } \\
\text { proteção social }\end{array}$ & $\begin{array}{c}\text { Marcos e } \\
\text { iniciativas da } \\
\text { saúde }\end{array}$ \\
\hline $\begin{array}{l}\text { 1930- } 1945 \\
\text { Estruturação } \\
\text { das bases para } \\
\text { o planejamento }\end{array}$ & $\begin{array}{l}\text { Primeiro } \\
\text { Governo Vargas: } \\
\text { Governo } \\
\text { provisório } \\
\text { (1930-34), } \\
\text { Governo } \\
\text { Constitucional } \\
\text { (1934-37), } \\
\text { Estado N ovo } \\
\text { ditatorial } \\
\text { (1937-45). }\end{array}$ & $\begin{array}{l}\text { - Projeto } \\
\text { nacionalista e } \\
\text { estatista; } \\
\text { - Impulso à } \\
\text { industrialização: } \\
\text { protecionismo e } \\
\text { papel do Estado nas } \\
\text { linhas de crédito e } \\
\text { na infraestrutura } \\
\text { industrial; } \\
\text { - Conformação de } \\
\text { órgãos eburocracia } \\
\text { estatal (ex.: DASP). }\end{array}$ & $\begin{array}{l}\text { Ênfase nos planos de } \\
\text { infraestrutura: - Plano } \\
\text { Especial de Obras Públicas } \\
\text { e Defesa Nacional (1939) } \\
\text { - Plano de Obras e } \\
\text { Equipamentos (1944) }\end{array}$ & $\begin{array}{l}\text { - Legislação } \\
\text { trabalhista } \\
\text { - Conformação } \\
\text { dos Institutos } \\
\text { de } \\
\text { Aposentadorias } \\
\text { e Pensões } \\
\text { (IAP) }\end{array}$ & $\begin{array}{l}\text { Criação de: } \\
\text { M inistério da } \\
\text { Educação e } \\
\text { Saúde Pública } \\
\text { (M ESP)- } \\
\text { controle de } \\
\text { doenças } \\
\text { específicas; } \\
\text { M inistério do } \\
\text { Trabalho } \\
\text { Indústria e } \\
\text { Comércio } \\
\text { (M TIC)- } \\
\text { assistência } \\
\text { médica } \\
\text { previdenciária } \\
\text { (IAP) }\end{array}$ \\
\hline $\begin{array}{l}\text { 1950-1963 } \\
\text { Planejamento } \\
\text { desenvolvimentista }\end{array}$ & $\begin{array}{l}\text { - Alternância de } \\
\text { governos } \\
\text { (Dutra, Vargas, } \\
\text { Café Filho, JK, } \\
\text { Jânio, Jango); } \\
\text { - "Anos } \\
\text { Dourados" (JK): } \\
\text { crescimento e } \\
\text { esperança; } \\
\text { - M omentos de } \\
\text { instabilidade } \\
\text { (suicídio de } \\
\text { Vargas, } \\
\text { renúncia de } \\
\text { Jânio); } \\
\text { - Curto período } \\
\text { parlamentarista. }\end{array}$ & $\begin{array}{l}\text { - Auge do } \\
\text { desenvolvimentismo; } \\
\text { - Alternância de } \\
\text { fases que } \\
\text { privilegiaram ajuste } \\
\text { (Dutra, Jânio) ou } \\
\text { expansão da atuação } \\
\text { do Estado voltada } \\
\text { para investimentos e } \\
\text { crescimento (Vargas, } \\
\text { JK); } \\
\text { - Criação de } \\
\text { estruturas } \\
\text { importantes: Banco } \\
\text { Nacional de } \\
\text { Desenvolvimento } \\
\text { Econômico } \\
\text { (BNDE), Petrobrás, } \\
\text { outras estatais; } \\
\text { - Criação da } \\
\text { Superintendência de } \\
\text { Desenvolvimento do } \\
\text { Nordeste } \\
\text { (SU DENE). }\end{array}$ & $\begin{array}{l}\text { - Plano Salte (Final } \\
\text { Governo Dutra - 1950): } \\
\text { ênfase em transportes e } \\
\text { energia, visando à } \\
\text { industrialização; aborda } \\
\text { setores de saúde e } \\
\text { alimentação, diferenciando } \\
\text { saúde pública e saúde } \\
\text { individual; } \\
\text {-Plano de M etas (Governo } \\
\text { JK -1956): energia, } \\
\text { transportes, indústria de } \\
\text { base, os setores de } \\
\text { alimentos e educação } \\
\text { correspondiam a 6,5\% dos } \\
\text { recursos. Sem proposta para } \\
\text { a saúde; } \\
\text { - Plano Trienal (Governo } \\
\text { Jango- 1963): visava ao } \\
\text { crescimento com melhoria } \\
\text { de condições de vida } \\
\text { (ênfase distributiva). } \\
\text { Educação, pesquisa e saúde } \\
\text { pública eram áreas-chave. A } \\
\text { saúde deveria integrar-se ao } \\
\text { desenvolvimento, que } \\
\text { objetivava o aumento da } \\
\text { produção e da } \\
\text { disponibilidade de bens e } \\
\text { serviços para a população, } \\
\text { incluindo os de saúde. }\end{array}$ & $\begin{array}{l}\text { - Expansão de } \\
\text { algumas } \\
\text { políticas } \\
\text { sociais; } \\
\text { - Agenda de } \\
\text { reformas de } \\
\text { base (Governo } \\
\text { Jango) } \\
\text { - Políticas de } \\
\text { aumentos } \\
\text { salariais (em } \\
\text { alguns } \\
\text { momentos) }\end{array}$ & $\begin{array}{l}\text { - Dicotomia das } \\
\text { políticas de } \\
\text { saúde } \\
\text { - Criação do } \\
\text { M inistério da } \\
\text { Saúde em } 1953 \\
\text { - acentua } \\
\text { caráter } \\
\text { estratégico no } \\
\text { combate de } \\
\text { grandes males. } \\
\text { - Difusão das } \\
\text { ideias dos } \\
\text { sanitaristas- } \\
\text { desenvolvimentistas: } \\
\text { saúdeadquire } \\
\text { significado } \\
\text { econômico, } \\
\text { político e } \\
\text { ideológico (III } \\
\text { Conferência } \\
\text { Nacional de } \\
\text { Saúde - 1963) }\end{array}$ \\
\hline
\end{tabular}


Quadro 1. continuação

\begin{tabular}{|c|c|c|c|c|c|}
\hline $\begin{array}{l}\text { Momentos } \\
\text { relevantes }\end{array}$ & $\begin{array}{l}\text { Contexto } \\
\text { político } \\
\text { nacional }\end{array}$ & $\begin{array}{c}\text { Modelo de } \\
\text { desenvolvimento/ } \\
\text { política econômica }\end{array}$ & $\begin{array}{l}\text { Principais instrumentos } \\
\text { de planejamento estatal }\end{array}$ & $\begin{array}{c}\text { Sistema de } \\
\text { proteção social }\end{array}$ & $\begin{array}{c}\text { Marcos e } \\
\text { iniciativas da } \\
\text { saúde }\end{array}$ \\
\hline $\begin{array}{l}\text { 1964-1979 } \\
\text { Planejamento } \\
\text { autoritário }\end{array}$ & $\begin{array}{l}\text { - Regime militar } \\
\text { ditatorial, com } \\
\text { diferentes fases; } \\
\text { - Nacionalismo, } \\
\text { ênfase na } \\
\text { segurança } \\
\text { nacional e no } \\
\text { "Brasil } \\
\text { potência"; } \\
\text { - Governo } \\
\text { M édici: } \\
\text { "milagre } \\
\text { econômico" e } \\
\text { endurecimento } \\
\text { político; } \\
\text { - Governo } \\
\text { Geisel: restrição } \\
\text { aos direitos civis } \\
\text { e políticos; } \\
\text { lema da } \\
\text { "abertura lenta, } \\
\text { gradual e } \\
\text { segura". }\end{array}$ & $\begin{array}{l}\text { - Desenvolvimentismo } \\
\text { autoritário; } \\
\text { - Busca de } \\
\text { fortalecimento do } \\
\text { planejamento em } \\
\text { médio e longo prazo } \\
\text { (aumento de } \\
\text { atribuições do M P - } \\
\text { SEPLAN e criação } \\
\text { do IPEA); } \\
\text { - Consolidação do } \\
\text { parque de empresas } \\
\text { estatais; } \\
\text { - Alternância de } \\
\text { políticas de } \\
\text { investimentos e de } \\
\text { estabilização. }\end{array}$ & 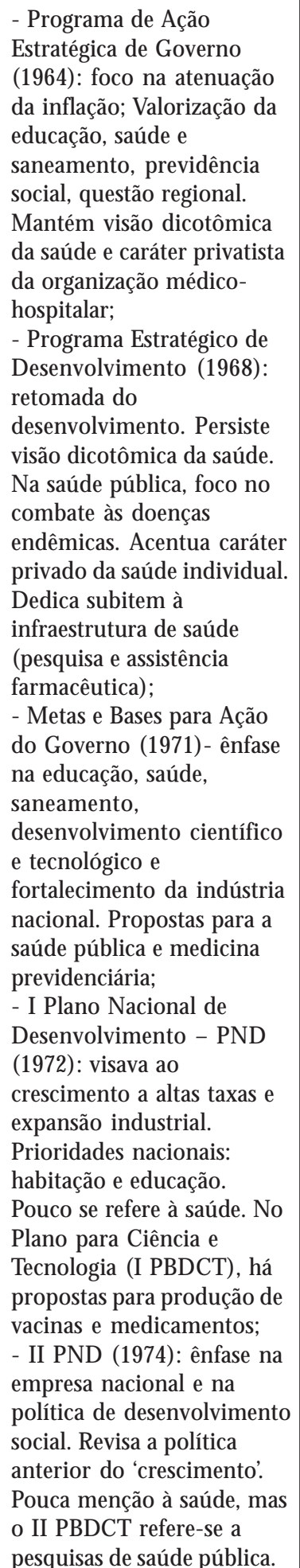 & $\begin{array}{l}\text { - Expansão do } \\
\text { sistema de } \\
\text { proteção social } \\
\text { centralizado, } \\
\text { fragmentado e } \\
\text { com distorções } \\
\text { no } \\
\text { financiamento } \\
\text { e prestação. } \\
\text { - Reorganização } \\
\text { da previdência } \\
\text { (unificação dos } \\
\text { IAPs no INPS; } \\
\text { conformação } \\
\text { do SIN PAS e } \\
\text { do INAM PS)- } \\
\text { Fases de } \\
\text { arrocho salarial. }\end{array}$ & $\begin{array}{l}\text { - Expansão da } \\
\text { medicina } \\
\text { previdenciária e } \\
\text { diminuição } \\
\text { relativa do } \\
\text { orçamento de } \\
\text { saúde pública } \\
\text { - Lei do Sistema } \\
\text { Nacional de } \\
\text { Saúde (1975) - } \\
\text { reitera } \\
\text { fragmentação } \\
\text { entre vertentes } \\
\text { previdenciária e } \\
\text { de saúde pública } \\
\text { M inistério da } \\
\text { Saúde: } \\
\text { - Plano Leonel } \\
\text { M iranda (1967) } \\
\text { - enfoque } \\
\text { restrito e } \\
\text { privatizante; } \\
\text { - Programa de } \\
\text { Interiorização } \\
\text { das Ações de } \\
\text { Saúde e } \\
\text { Saneamento } \\
\text { (1976) - buscava } \\
\text { estender serviços } \\
\text { de atenção } \\
\text { básica no } \\
\text { Nordeste do } \\
\text { país. } \\
\text { Vertente } \\
\text { previdenciária: } \\
\text { - Criação do } \\
\text { M inistério da } \\
\text { Previdência e } \\
\text { Assistência } \\
\text { Social; } \\
\text { - Plano de } \\
\text { Pronta Ação } \\
\text { (1974) } \\
\text { - expansão da } \\
\text { cobertura em } \\
\text { saúde; } \\
\text { - Fundo de } \\
\text { Apoio ao } \\
\text { Desenvolvimento } \\
\text { Social (1974) } \\
\text { - recursos para a } \\
\text { construção de } \\
\text { hospitais } \\
\text { privados. }\end{array}$ \\
\hline
\end{tabular}




\begin{tabular}{|c|c|c|c|c|c|}
\hline \multicolumn{6}{|c|}{ Quadro 1. continuação } \\
\hline $\begin{array}{l}\text { Momentos } \\
\text { relevantes }\end{array}$ & $\begin{array}{l}\text { Contexto } \\
\text { político } \\
\text { nacional }\end{array}$ & $\begin{array}{c}\text { Modelo de } \\
\text { desenvolvimento/ } \\
\text { política } \\
\text { econômica }\end{array}$ & $\begin{array}{l}\text { Principais instrumentos de } \\
\text { planejamento estatal }\end{array}$ & $\begin{array}{l}\text { Sistema de } \\
\text { proteção } \\
\text { social }\end{array}$ & $\begin{array}{c}\text { Marcos e } \\
\text { iniciativas da } \\
\text { saúde }\end{array}$ \\
\hline $\begin{array}{l}\text { 1980-1994 } \\
\text { Crise do } \\
\text { planejamento } \\
\text { estatal }\end{array}$ & $\begin{array}{l}\text { Crise do Estado } \\
\text { e } \\
\text { democratização: } \\
\text { - Nova } \\
\text { República; } \\
\text { - Assembléia } \\
\text { Constituinte e } \\
\text { Constituição de } \\
\text { 1988; } \\
\text { - Governo } \\
\text { Collor (1990- } \\
\text { 1992): } \\
\text { liberalização } \\
\text { econômica, } \\
\text { instabilidade e } \\
\text { impeachment; } \\
\text { - Governo } \\
\text { Itamar (1993- } \\
\text { 1994): } \\
\text { transição. }\end{array}$ & $\begin{array}{l}\text { Anos 1980: crise do } \\
\text { desenvolvimentismo } \\
\text { conservador } \\
\text { - Ênfase no } \\
\text { controle da } \\
\text { inflação e } \\
\text { estabilização } \\
\text { Anos 1990: } \\
\text { hegemonia do } \\
\text { modelo neoliberal } \\
\text { - Predomínio de } \\
\text { políticas de curto } \\
\text { prazo, controle da } \\
\text { inflação, ajuste } \\
\text { fiscal, abertura } \\
\text { econômica, } \\
\text { privatizações de } \\
\text { empresas estatais; } \\
\text { Plano Real (1994) }\end{array}$ & $\begin{array}{l}\text { Anos 1980: } \\
\text { - III PND (implantação } \\
\text { limitada); } \\
\text { - Vários planos de } \\
\text { estabilização monetária; } \\
\text { - Constituição de 1988: planos } \\
\text { plurianuais (PPA) - } \\
\text { instrumentos de } \\
\text { planejamento de médio prazo, } \\
\text { que buscam a articulação entre } \\
\text { planejamento e orçamento. } \\
\text { Os PPA compreendem } \\
\text { diretrizes estratégicas e } \\
\text { programas referentes às várias } \\
\text { políticas; } \\
\text { - PPA 1991-1995: feito para } \\
\text { cumprir exigência } \\
\text { constitucional - implantação } \\
\text { limitada, em face da } \\
\text { instabilidade política e } \\
\text { econômica. }\end{array}$ & $\begin{array}{l}\text { Anos 1980: } \\
\text { - Expansão } \\
\text { fragmentada e } \\
\text { reestruturação } \\
\text { progressista de } \\
\text { algumas } \\
\text { políticas } \\
\text { 1990-1994: } \\
\text { - Contenção } \\
\text { de gastos } \\
\text { sociais; } \\
\text { - Obstrução à } \\
\text { lógica } \\
\text { constitucional } \\
\text { da Seguridade } \\
\text { Social }\end{array}$ & $\begin{array}{l}\text { Anos 1980: } \\
\text { - Universalização } \\
\text { gradativa da } \\
\text { assistência à } \\
\text { saúde; } \\
\text { - Reconhecimento } \\
\text { do direito à saúde } \\
\text { e unificação do } \\
\text { sistema (Sistema } \\
\text { Único de Saúde- } \\
\text { SUS) } \\
\text { 1990-1994: - Leis } \\
\text { da Saúde } \\
\text { - Início da } \\
\text { implementação } \\
\text { do SUS } \\
\text { - Ênfase na } \\
\text { descentralização } \\
\text { político- } \\
\text { administrativa } \\
\text { - Dificuldades no } \\
\text { financiamento }\end{array}$ \\
\hline $\begin{array}{l}\text { 1995- } 2002 \\
\text { Planejamento } \\
\text { gerencialista }\end{array}$ & $\begin{array}{l}\text { - Governos } \\
\text { Fernando } \\
\text { Henrique } \\
\text { Cardoso (1995- } \\
\text { 1998;1999- } \\
\text { 2002): } \\
\text { democratização, } \\
\text { liberalização e } \\
\text { maior } \\
\text { estabilidade } \\
\text { econômica e } \\
\text { política. }\end{array}$ & $\begin{array}{l}\text { Predomínio do } \\
\text { liberalismo } \\
\text { econômico: } \\
\text { - Projeto de } \\
\text { inserção do país } \\
\text { em um cenário } \\
\text { mundial } \\
\text { competitivo; } \\
\text { - Prossegue ênfase } \\
\text { na estabilidade } \\
\text { econômica, } \\
\text { abertura de } \\
\text { mercados, } \\
\text { privatizações; } \\
\text { - Fragilidade da } \\
\text { política industrial; } \\
\text { - Reformas } \\
\text { constitucionais; } \\
\text { - Reforma do } \\
\text { aparelho do } \\
\text { Estado; } \\
\text { - Descentralização, } \\
\text { redução do } \\
\text { funcionalismo, } \\
\text { ênfase no “Estado } \\
\text { gerencial”, criação } \\
\text { de agências } \\
\text { reguladoras. }\end{array}$ & $\begin{array}{l}\text { - PPA 1996-1999: } \\
\text { consolidação da estabilidade; } \\
\text { retomada dos investimentos } \\
\text { seria consequência. Visa à } \\
\text { construção de Estado } \\
\text { moderno e eficiente; redução } \\
\text { dos desequilíbrios espaciais e } \\
\text { sociais; modernização } \\
\text { produtiva. Conceitos como } \\
\text { eixos nacionais de integração e } \\
\text { projetos estruturantes; Saúde: } \\
\text { redução da mortalidade } \\
\text { infantil e acesso da população } \\
\text { a serviços básicos de saúde; } \\
\text { - Projeto Brasil 2020 (1998): } \\
\text { construção de cenários } \\
\text { visando à orientação } \\
\text { estratégica de longo prazo; } \\
\text { - PPA 2000-2003: aumento da } \\
\text { competitividade da economia; } \\
\text { ênfase na gestão por } \\
\text { resultados; Saúde: qualidade e } \\
\text { eficiência do SUS; Saúde da } \\
\text { Família, da mulher; redução da } \\
\text { mortalidade infantil; } \\
\text { profissionalização da } \\
\text { enfermagem. }\end{array}$ & $\begin{array}{l}\text { - Avanços } \\
\text { institucionais } \\
\text { em algumas } \\
\text { políticas- } \\
\text { Expansão das } \\
\text { políticas } \\
\text { assistenciais, } \\
\text { com destaque } \\
\text { para as de } \\
\text { transferência } \\
\text { de renda. }\end{array}$ & $\begin{array}{l}\text { - Descentralização } \\
\text { sob regulação } \\
\text { federal (normas e } \\
\text { portarias, } \\
\text { incentivos } \\
\text { financeiros). } \\
\text { - Instrumentos de } \\
\text { planejamento: } \\
\text { planos anuais, } \\
\text { projetos } \\
\text { temáticos. } \\
\text { - Iniciativas de } \\
\text { pactos } \\
\text { intergovernamentais } \\
\text { baseados em } \\
\text { prioridades } \\
\text { negociadas } \\
\text { (Agenda de } \\
\text { Saúde, Pacto de } \\
\text { Atenção Básica, } \\
\text { Programação da } \\
\text { Vigilância } \\
\text { Epidemiológica). }\end{array}$ \\
\hline
\end{tabular}

Fonte: Elaboração dos autores, a partir de diversas referências. 
O contexto do governo Lulaeo planejamento

Ainda queo governo Lula não tenha trazido rupturas radicais no modelo de atuação do Estado, épossível identificar elementos demudança, com expressão no planejamento.

No plano econômico, no primeiro mandato (2003-2006), instaurou-se um modelo híbrido, caracterizado pela combinação de mecanismos de mercado e forte coordenação estatal. Houve esforços de manutenção da estabilidade associadosà implantação de políticas sel etivas de desenvolvimento industrial e apoio às empresas nacionais. Ressalte-se a revalorização do Banco $\mathrm{Na}$ cional do Desenvolvimento Econômico e Social (BNDES), como protagonista de investimentos voltados para o setor privado, inserido em uma política de fomento à indústria, à inovação tecnológica e ao comércio exterior ${ }^{24}$. Em 2007, no início do segundo mandato, em face da promessa de enfatizar as políticas de desenvolvimento, foi lançado o Plano deAceleração do Crescimento $(P A C)$, um programa que envolve medidas econômicas e investimentos em infraestrutura ${ }^{25}$.

Em relação à proteção social, há autores que ressaltam continuidades em relação aos anos noventa ${ }^{26}$ ou que advertem para a persistência de distorções estruturais e da não integração entre as políticas da seguridade social, o que prejudicaria a concretização da universalidade ${ }^{27}$. Um estudo recente identifica diferentes institucionalidades da política social no período, com um momento de transição no primeiro governo e a conformação de uma "institucionalidade neodesenvolvimentista" no segundo governo Lula ${ }^{28}$.

Em que pesem as controvérsias, observa-se a implantação uma agenda social que tem contribuído para avanços no âmbito da cidadania, destacando-se as políticas voltadas para os pobres (principalmente o Programa Bolsa Família) e as orientadas para grupos específicos. No entanto, persistiu a evolução fragmentada de políticas sociais, com iniciativas rarefeitas de coordenação governamental, em comparação à complexidade e ao adensamento institucional das áreas específicas.

No âmbito do planejamento, a partir de2003, foram adotadas iniciativas ligadas ao gabinete presidencial eà Casa Civil, que deveriam ser conduzidas em conjunto com o Ministério do Planejamento, Orçamento e Gestão, em articulação com os ministérios setoriais. Uma delas foi a definição de uma agenda estratégica, que envolveu a identificação pelos ministérios de mais de duzentas iniciativas prioritárias e a posterior sele ção de 45 metas prioritárias pela alta direção de governo. Destaque-se ainda o projeto "Brasil em 3 Tempos" $(2007,2015,2022)$ que, além de incluir análise situacional, construção de cenários, busca de soluções estratégicas e monitoramento, procurava valorizar o plano como processo e a pactuação nacional ${ }^{29}$.

Observa-se também, a partir de 2003, uma recomposição de quadros de servidores na administração federal ${ }^{30}$, diferenciada por áreas.

O planejamento em saúde de 2003 a 2010: estratégias e instrumentos

As estratégias de planejamento em saúdeno período tiveram propósitos variados e se expressaram em instrumentos de planejamento específicos. A articulação entre planejamento eorçamento se deu, como nos anos noventa, por meio dos PPA (2004-2007 e 2008-2011). Esses PPA, elaborados sob um mesmo presidente, apresentaram diferenças quanto à orientação da estratégia de desenvolvimento. Enquanto o primeiro enfatizou a redução da desigualdade e maior inclusão social, o segundo apresentou orientação fortemente econômica, visando à aceleração do crescimento.

Estas diferenças refletiram na saúde, visto que os PPA influenciaram, em cada mandato, as estratégias e instrumentos de planejamento de iniciativa do M inistério da Saúde. 0 fortalecimento da função planejadora federal, em uma perspectiva mais integrada edebatida entreáreas, foi buscado por meio da construção de um Plano N acional deSaúde (2004-2007). A val orização da coordenação intergovernamental para o alcance de prioridades da política se traduziu na elaboração do Pacto pela Saúde (2006). Por fim, o esforço de inserção da saúde em um projeto de desenvolvimento em transformação se expressou na construção do plano M ais Saúde (2008-2011).

O planejamento em saúde

no primeiro governo Lula

O PPA 2004-2007 foi elaborado em um contexto de relativa estabilidade econômica e política, com a participação da sociedade civil eesferas de governo na definição de objetivos e prioridades. Tal PPA propunha a integração de políticas de investimento para o crescimento, políticas sociais e redistribuição de renda, para reduzir as desigualdades e promover a inclusão social ${ }^{31}$.

O plano estabeleceu cinco dimensões (social, econômica, regional, ambiental e democrática) e 
três megaobjetivos, que buscavam articular o desenvolvimento econômico ao desenvolvimento social com democracia. Contudo, o plano configurou uma dubiedade de orientação estratégica, pois apesar de assumir como objetivos prioritários a inclusão social e a desconcentração de renda, manteve políticas macroeconômicas de estabilização que restringiam a efetiva consolidação desta diretriz ${ }^{32}$.

Quanto à saúde, o PPA 2004 apresenta diretrizes abrangentes, que reafirmam 0 direito à atenção integral à saúdee indica a necessidade de aprimoramento dos mecanismos de financiamento e redução das desigualdades regionais, para ampliar o acesso da população a serviços de qualidade.

O plano definea efetivação da atenção básica articulada aos demais níveis de atenção como meta prioritária eapresenta um conjunto de proposições para cada área - atenção, vigilâncias, ciência etecnologia, trabal ho eeducação, participação social - e para programas específicos.

O PPA também estabelece a inserção da saúdenum projeto abrangente de inclusão social ea articulação entre as políticas sociais e outras políticas. Assim, são definidos programas e ações intersetoriais em que o M inistério da Saúde assume o papel de um dos executores, junto a outros ministérios.

Ainda em 2003, o M inistério da Saúde desencadeou a elaboração de um Plano Nacional de Saúde, que foi balizado pelas diretrizes do PPA em construção. Após várias rodadas de discussão no interior do M inistério e com outros grupos do setor saúde, foi editado em dezembro de 2004 o primeiro Plano N acional deSaúdedo SUS.

No Plano Nacional de Saúde (PNS), foram definidos objetivos voltadosà implementação do SUS, tendo como propósito promover o cumprimento do direito constitucional à saúde, visando à redução do risco de agravos e ao acesso universal e igualitário às ações para sua promoção, proteção e recuperação, assegurando a equidade na atenção, aprimorando os mecanismos de financiamento, diminuindo as desigualdades regionai $s^{33}$.

O PNS representava para a nova gestão ministerial um plano estratégico que explicitava os resultados de saúde a serem buscados no período do PPA 2004-2007 e foi assumido como um instrumento de referência à atuação dos gestores do SUS. 0 plano propôs como eixos de orientação, para as esferas municipal, estadual e regional, a redução das desigualdades em saúde, a ampliação do acesso com a qualificação e humanização da atenção, a redução dos riscos e agravos, a re- forma do modelo de aten ção e o aprimoramento da gestão, financiamento e controle social.

A responsabilidade pela gestão, monitoramento e avaliação do PNS coube à SecretariaExecutiva do M inistério da Saúde e cada órgão e entidade federal deveria readequar programas e atividades aos objetivos, diretrizes e metas estabelecidas no plano.

De fato, o PNS foi um instrumento importante e diferente dos apresentados em gestões ministeriais anteriores (agenda de saúde, quadro de metas, planos anuais, projetos temáticos ou relatórios de gestão) porque firmou o compromisso político do gestor federal com a saúde, dando visibilidade às prioridades nacionais de forma mais articulada e orientando os acordos entre os gestores, que seriam retomados em outro instrumento: o Pacto pela Saúde de 2006.

A elaboração do Pacto pela Saúdefoi desencadeada a partir da necessidade de mudanças no relacionamento entreas efferas degoverno na saúde. Prevalecia entreos dirigentes uma visão crítica ao modelo de condução federal da descentralização no SUS anterior, caracterizado por intensa normatização atrelada a incentivos financeiros. Em 2003 e 2004, a discussão esteve voltada para o denominado Pacto de Gestão, com maior ênfasenos aspectos referentes à descentral ização, ao financiamento e à regionalização. Em meados de 2005, houve ampliação do escopo da proposta.

A pós ampla discussão, o documento contendo as diretrizes do Pacto pela Saúde 2006- Consolidação do SUS foi aprovado na Comissão Intergestores Tripartite e no Conselho Nacional de Saúdee publicado, incluindo três dimensões: pela Vida, em D efesa do SU S e de Gestão ${ }^{34}$. Posteriormente, vários documentos federais descrevem os instrumentos operacionais do pacto e fornecem orientações para políticas específicas.

Em relação ao planejamento, são apresentadas as diretrizes e objetivos do Sistema de Planejamento no SUS, cuja ênfase recai sobre o processo de pactuação intergovernamental e os instrumentosa serem adotados (Planos deSaúdee Programação Pactuada e Integrada). São destacados pontos prioritários, como a adoção do critério de necessidades de saúde para o planejamento e a programação, a adequação de instrumentos e a cooperação entre esferas de governo para o fortalecimento ea equidade no planejamento.

Por fim, o Pacto pela Saúde propõe a formalização dos acordos estabelecidos entre as esferas de governo por meio da assinatura de termos de compromisso de gestão, que compreendem responsabilidades, objetivos e metas associados a 
indicadores demonitoramento. A adesão aos termos substitui os antigos processos de habilitação previstos nas normas operacionais do SUS como requisito para transferência de responsabilidades e recursos.

Ressalte-seque o Pacto pela Saúde representa uma inflexão na forma de atuação federal e nas relações federativas no SUS, acentuan do a necessidade de cooperação intergovernamental na política de saúde. Além disso, a concepção de regionalização embutida no pacto representa um "novo ciclo" da descentralização da saúde no Brasil ${ }^{35}$. Ao mesmo tempo em que resgata seu conteúdo político, admite que a organização espacial do sistema de saúde deva levar em conta a diversidade do território brasileiro e buscar a complementaridadeentreas regiões. Entretanto, evidenciam-se alguns limites do pacto como um instrumento de planejamento, de indução e coordenação federal de políticas.

Embora a pactuação federativa seja a principal estratégia e o eixo transversal das proposições do pacto, a base para a el aboração dos compromissos é a expectativa de solidariedade entre os entes e não o planejamento nacional, estadual ou local. Um dos pontos frágeis da proposta, portanto, é o descolamento entre os processos de planejamento e de pactuação intergovernamental. Isso é evidenciado pela limitada ênfase no diagnóstico, como condição prévia à formalização de compromissos entre os gestores, pelas dificuldades de adaptação dos processos de pactuação e definição de prioridades a cada realidade situacional ${ }^{36}$ e pela in definição das estratégias e instrumentos para 0 alcance das metas (investimentos, incorporação e regulação tecnológica, garantia de recursos humanos capacitados, protocolos de aten ção e mecanismos de assegurar 0 acesso, entre outros).

Outro aspecto refere-seà relação entre o processo de celebração dos pactos e o modelo de intervenção federal. Esta relação poderia ser aprimorada, com maior valorização do planejamento nacional, que não se restringe à coordenação de um processo "de base local e ascendente", visto que existem atributos próprios do planejamento em cada âmbito territorial.

Por fim, não estão claras as relações entre os processos de regionalização e de celebração dos pactos, visto que, nas bases atuais, este último pode ocorrer sem que o primeiro seja de fato fortalecido. Os Colegiados de Gestão Regional, em implantação nas regiões de saúde intraestaduais, ainda não apresentam estrutura e recursos que permitam o desenvolvimento de parce- rias e a resolução de conflitos federativos. Falta avançar nos instrumentos de planejamento, regulação e financiamento propostos para a conformação de sistemas públicos de saúde regionais em diferentes recortes territoriais.

O planejamento em saúde

no segundo governo Lula

O PPA 2008-2011 insere-se num contexto de continuidade de governo e num cenário econômico favorável ao crescimento, que exigia políticas de investimento e de expansão econômica. 0 plano propõe três eixos estratégicos: crescimento econômico, com a definição do Programa de Aceleração do Crescimento (PAC), educação de qualidade, com o Plano de Desenvolvimento da Educação (PDE) e a agenda social.

$\mathrm{Na}$ agenda social, identifica-se a ênfase em políticas de investimento articuladas ao PAC: a Agenda Social priorizará iniciativas voltadas para a acessibilidade na habitação de interesse social, nos transportes e nas escolas; atendimento de reabilitação e concessão de órteses e próteses no Sistema Único de Saúde (SUS); educação inclusiva e inserção no mercado de trabalho ${ }^{37}$.

A orientação para a saúde mantém a tônica na expansão da atenção básica (ampliação das equipes de saúde da família e saúde bucal), indicando como desafio a melhoria do SUS. O plano difere bastante do PPA anterior, com um diagnóstico tímido dos desafios do setor e com pequena articulação com outras áreas e políticas de governo.

Sem dúvida, o eixo mais valorizado do PPA 2008 é o PAC, lançado no início de 2007 como marco da busca de um novo modelo de desenvolvimento no segundo governo Lula. No rastro do PAC, alguns ministérios formularam propostas setoriais. O M inistério da Educação lançou o Plano de Desenvolvimento da Educação no primeiro semestre de 2007, possibilitando que este fosse incluído no PPA.

Já o M inistério da Saúde, apesar deter desencadeado o processo de formulação do "PAC-Saúde" no primeiro semestre, só conseguiu lançá-lo em dezembro de 2007, após a divulgação do PPA. 0 processo de planejamento envolveu a mobilização das áreas do ministério para a proposição de medidas e metas objetivas, sob coordenação da Secretaria Executiva e com o apoio de consultoria externa, bem como a montagem de um sistema de monitoramento.

O plano, intitulado "M ais Saúde - Direito de Todos", destaca em suas diretrizes que a saúde 
possui duas dimensões que se associam a uma nova aposta de desenvolvimento para o Brasil: a de proteção social e a econômica. Compreende uma proposta ousada de articular a reforma sanitária brasileira e a consolidação de um sistema de saúde universal com um novo padrão de desenvolvimento comprometido com o crescimento, o bem-estar e a equidade. Valoriza a promoção da saúde, a intersetorialidade e o fortalecimento do complexo produtivo e de inovação em saúde para tal transformação. Ressalta ainda a importância da coordenação federativa, com menção ao Pacto pela Saúde e à regionalização. Por fim, aponta a necessidade de equacionar a situação de subfinanciamento do SUS para que tais diretrizes sejam al cançadas ${ }^{38}$.

As propostas para o setor são apresentadas inicialmente em sete eixos (Tabela 1). Ressalte-se quea Fundação Nacional da Saúdehavia seantecipado e divulgado em setembro de 2007 o PACFUNASA, contendo propostas de saneamento básico que se aproximavam da lógica de infraestrutura do PAC geral equedestacavam grupos específicos valorizados na agenda social do governo (indígenas, quilombolas). Tais ações foram incorporadas a edições posteriores do M ais Saúde.

Em cada eixo, são propostas medidas e metas físicas e financeiras, com explicitação do orçamento assegurado e de recursos para "expansão" de ações, que foram negociados com a área econômica. A Tabela 1 mostra que $86 \%$ dos recursos do plano se referiam ao eixo de atenção à saúde e que os eixos que mais dependeriam de novos recursos seriam a promoção da saúde, 0 complexo industrial da saúde ea cooperação internacional.
O M ais Saúde é o principal instrumento de planejamento da saúdeno segundo governo Lula, bastante vinculado ao projeto do então M inistro da Saúde, de expansão de ações e de busca de uma nova inserção da saúde em um modelo de desenvolvimento em transformação. No entanto, duas limitações podem ser apontadas.

A primeiraéquenem todos os eixos do documento apresentam a mesma abrangência e traduzem deforma igual mente consistenteas políticas sob condução das áreas específicas. A segunda e mais decisiva é que o plano foi lançado no mês em que o Congresso Nacional decidiu pela não aprovação da continuidade da Contribuição Provisória sobre Movimentação Financeira (CPM F), o que comprometeu sua execução, particularmenteno queconcerneà expansão de ações. I sso foi enfatizado pela cúpula do Ministério da Saúde ao final de 2009, quando foi lançada a terceira versão do Plano, que explicita ações prioritárias em face das restrições orçamentárias ${ }^{39}$.

O Quadro 2 apresenta a caracterização dosinstrumentos de planejamento em saúde analisados.

\section{Consideraçõesfinais}

O Brasil apresenta uma longa história de planejamento estatal, embora sob um modelo específico, caracterizado pela centralização federal e por longos períodos de autoritarismo. Foi no âmbito da industrialização que o planejamento teve indubitável destaque, embora se registrem estratégias de planejamento em outras políticas. A partir dosanos oitenta, houve uma fragilização do planejamento nacional em função da crise do Estado.

Tabela 1. Previsão orçamentária inicial do Mais Saúde 2008-2011, por eixos.

\begin{tabular}{lrrrrr}
\hline \multicolumn{1}{c}{ Eixos } & Assegurado(R\$) & Expansão(R\$) & Total(R\$) & $\begin{array}{c}\text { \% Expansão/ } \\
\text { Total Eixo }\end{array}$ & $\begin{array}{r}\text { \% do Eixo/ } \\
\text { Total Plano }\end{array}$ \\
\hline Promoção da saúde & 531.080 .890 & 1.675 .052 .481 & 2.206 .133 .371 & 75,9 & 2,4 \\
Atenção à Saúde & 60.098 .608 .401 & 20.310 .278 .055 & 80.408 .886 .456 & 25,3 & 86,0 \\
Complexo Industrial da Saúde & 1.159 .213 .000 & 854.695 .652 & 2.013 .908 .652 & 42,4 & 2,2 \\
Força de Trabalho em Saúde & 1.734 .180 .000 & 824.864 .343 & 2.559 .044 .343 & 32,2 & 2,7 \\
Qualificação da gestão & 1.339 .350 .000 & 603.634 .813 & 1.942 .984 .813 & 31,1 & 2,1 \\
Participação social & 267.000 .000 & 29.450 .870 & 296.450 .870 & 9,9 & 0,3 \\
Cooperação internacional & 15.000 .000 & 43.100 .000 & 58.100 .000 & 74,2 & 0,1 \\
Saneamento* & 4.000 .000 .000 & 0 & 4.000 .000 .000 & 0,0 & 4,3 \\
Total & 69.144 .432 .291 & 24.341 .076 .214 & 93.485 .508 .505 & 26,0 & 100,0 \\
\hline
\end{tabular}

Fonte: Brasil. M inistério da Saúde ${ }^{38}$.

* Nota: Na 1ª edição do M ais Saúde, de 2007, não consta o Saneamento. Na 2a edição, de 2008, utilizada para construção da tabela, o PACSaneamento aparecia como anexo. $\mathrm{Na}$ 3a edição, de2009, o Saneamento éincorporado como eixo. 
Quadro 2. Instrumentos federais de planejamento em saúde no período de 2003 a 2010.

\begin{tabular}{|c|c|c|c|}
\hline Instrumento & Propósito & Forma/Conteúdo & Processo de elaboração \\
\hline $\begin{array}{l}\text { PPA } \\
\text { 2004-2007 } \\
\text { Brasil de } \\
\text { todos: } \\
\text { participação e } \\
\text { inclusão }\end{array}$ & $\begin{array}{l}\text { Estratégia de desenvolvimento } \\
\text { de longo prazo sob quatro } \\
\text { eixos: } \\
\text { 1. Inclusão social e } \\
\text { desconcentração de renda } \\
\text { com vigoroso crescimento do } \\
\text { produto e do emprego; } \\
\text { 2. Crescimento } \\
\text { ambientalmente sustentável, } \\
\text { redutor das disparidades } \\
\text { regionais, dinamizado pelo } \\
\text { mercado de consumo de } \\
\text { massa, por investimentos e } \\
\text { por elevação da produtividade; } \\
\text { 3. Redução da vulnerabilidade } \\
\text { externa por meio da expansão } \\
\text { das atividades competitivas } \\
\text { que viabilizam o crescimento } \\
\text { sustentado; } \\
\text { 4. Fortalecimento da } \\
\text { cidadania e da democracia. }\end{array}$ & $\begin{array}{l}\text { Orientação estratégica de governo } \\
\text { M egaobjetivo I- dimensão social: visa à } \\
\text { redução das desigualdades sociais ea } \\
\text { inclusão social; } \\
\text { M egaobjetivo II - dimensões econômica, } \\
\text { regional e ambiental: visa ao crescimento } \\
\text { com geração de renda e emprego, } \\
\text { ambientalmente sustentável e redutor das } \\
\text { desi gualdades regionais; } \\
\text { M egaobjetivo III- dimensão democrática: } \\
\text { visa à expansão da cidadania e o } \\
\text { fortalecimento da democracia. } \\
\text { Orientação estratégica } \\
\text { do M inistério da Saúde } \\
\text { Promover a atenção integral à saúde, } \\
\text { aprimorando os mecanismos de } \\
\text { financiamento, reduzindo as desigualdades } \\
\text { regionais e ampliando o acesso da população } \\
\text { a ações e serviços de qualidade e } \\
\text { humanizados, com as metas: } \\
\text { - efetivar a atenção básica como estratégia } \\
\text { de acesso do cidadão ao SUS; } \\
\text { - reorganizar os hospitais com a inversão da } \\
\text { lógica de pagamento por procedimentos } \\
\text { para a de agravos prioritários ea } \\
\text { estruturação de uma rede de atenção às } \\
\text { urgências e emergências; } \\
\text { - estímulo a modelos alternativos de atenção } \\
\text { especializada, evitando a fragmentação da } \\
\text { atenção e as intervenções desnecessárias. }\end{array}$ & $\begin{array}{l}\text { Participação da sociedade civil } \\
\text { e das esferas de governo: } \\
\text { 1- fóruns de participação social } \\
\text { em todas as UF; } \\
\text { 2- reuniões no Conselho de } \\
\text { Desenvolvimento Econômico } \\
\text { e Social; } \\
\text { 3- reuniões gerais e regionais } \\
\text { com os secretários de } \\
\text { planejamento dos estados; } \\
\text { 4- reuniões com os conselhos } \\
\text { de classe e representantes da } \\
\text { sociedade civil patrocinadas } \\
\text { pelos ministérios específicos. }\end{array}$ \\
\hline $\begin{array}{l}\text { PNS } \\
2004-2007 \\
\text { Um pacto pela } \\
\text { saúde no } \\
\text { Brasil }\end{array}$ & $\begin{array}{l}\text { Promover o cumprimento do } \\
\text { direito constitucional à saúde, } \\
\text { visando à redução do risco de } \\
\text { agravos e ao acesso universal e } \\
\text { igualitário às ações para sua } \\
\text { promoção, proteção e } \\
\text { recuperação, assegurando a } \\
\text { equidade na atenção, } \\
\text { aprimorando os mecanismos } \\
\text { de financiamento, } \\
\text { diminuindo as desigualdades } \\
\text { regionais e provendo serviços } \\
\text { de qualidade, oportunos e } \\
\text { humanizados;i ndica } \\
\text { necessidade de uma agenda } \\
\text { estratégica para a melhoria da } \\
\text { saúde no país com: } \\
\text { - revisão do modelo de } \\
\text { financiamento; } \\
\text { - definição de uma política de } \\
\text { investimento direcionada para } \\
\text { a redução das desigualdades no } \\
\text { Brasil; } \\
\text { - efetivação de um pacto de } \\
\text { gestão entre os gestores das } \\
\text { três esferas. }\end{array}$ & $\begin{array}{l}\text { Eixos de orientação para a discussão das } \\
\text { prioridades nas esferas municipal, estadual } \\
\text { e regional: } \\
\text { 1. Redução das desigualdades em saúde; } \\
\text { 2. Ampliação do acesso com a qualificação } \\
\text { e humanização da atenção; } \\
\text { 3. Redução dos riscos e agravos; } \\
\text { 4. Reforma do modelo de atenção; } \\
\text { 5. Aprimoramento dos mecanismos de } \\
\text { gestão, financiamento e controle social. } \\
\text { Esta definição de prioridades indica a } \\
\text { responsabilidade de cada esfera de governo } \\
\text { e a necessidade de recursos. Exige um } \\
\text { ambiente de efetiva pactuação entre U nião, } \\
\text { estados e municípios, na lógica do } \\
\text { estabelecimento de um pacto de gestão, } \\
\text { com a revisão do processo de gestão e da } \\
\text { relação intergestores, afirmando } \\
\text { compromissos entre gestores e a } \\
\text { responsabilidade sanitária. }\end{array}$ & $\begin{array}{l}\text { Processo de construção } \\
\text { envolvendo amplo conjunto } \\
\text { de atores: } \\
\text { 1- Seminário com técnicos do } \\
\text { MS, CN S, CONASS, } \\
\text { CONASEM S, M POG e outras } \\
\text { áreas do governo federal; } \\
\text { 2- Pesquisa junto a } \\
\text { partici pantes da 12a } \\
\text { Conferência N acional de } \\
\text { Saúde para sugestões de } \\
\text { prioridades e opiniões; } \\
\text { 3- Discussão nos colegiados e } \\
\text { fóruns internos do M S, CIT e } \\
\text { CN S; } \\
\text { 4- Elaboração de pré-proposta } \\
\text { do plano com base em } 12 \\
\text { CNS, Projeto Saúde } 2004 \text { e } \\
\text { PPA Governo Federal; } \\
\text { 5- Nova rodada de discussão } \\
\text { dos órgãos e entidades do M S; } \\
\text { 6- Oficinas de trabalho } \\
\text { macrorregionais com técnicos } \\
\text { e gestores das três esferas de } \\
\text { governo na saúde; } \\
\text { 7- Proposta encaminhada para } \\
\text { o CNS em agosto de } 2004 \text {. }\end{array}$ \\
\hline
\end{tabular}


Quadro 2. continuação

\begin{tabular}{|c|c|c|c|}
\hline Instrumento & Propósito & Forma/Conteúdo & Processo de elaboração \\
\hline $\begin{array}{l}\text { Pacto pela } \\
\text { Saúde } \\
\text { Pactos pela } \\
\text { Vida, em } \\
\text { Defesa do } \\
\text { SUS e de } \\
\text { Gestão }\end{array}$ & $\begin{array}{l}\text { Corresponde ao pacto firmado } \\
\text { entre os três gestores do SUS } \\
\text { para a reforma de aspectos } \\
\text { institucionais vigentes, } \\
\text { promovendo inovações nos } \\
\text { processos e instrumentos de } \\
\text { gestão que visam alcançar } \\
\text { maior efetividade, eficiência e } \\
\text { qualidade de suas } \\
\text { respostas.Redefine } \\
\text { responsabilidades coletivas por } \\
\text { resultados sanitários em } \\
\text { função das necessidades de } \\
\text { saúde da população e na busca } \\
\text { da equidade social. }\end{array}$ & $\begin{array}{l}\text { Inclui três dimensões: } \\
\text { - Pacto pela Vida: corresponde à definição } \\
\text { de prioridades sanitárias, que se traduzem } \\
\text { em objetivos e metas de melhoria das } \\
\text { condições de saúde da população, a serem } \\
\text { acordadas pelas três esferas de governo; } \\
\text { - Pacto em Defesa do SU S: indica a } \\
\text { necessidade de um movimento político } \\
\text { amplo, explicitando iniciativas e ações } \\
\text { para garantia dos princípios e diretrizes da } \\
\text { reforma sanitária, que transcendam os } \\
\text { limites setoriais e aumentem a base de } \\
\text { apoio à política de saúde nos governos e } \\
\text { na sociedade; } \\
\text { - Pacto de Gestão: dimensão com maior } \\
\text { densidade e detalhamento, estabelece } \\
\text { diretrizes para o aprimoramento da gestão } \\
\text { do SUS em oito aspectos: } \\
\text { descentralização, regionalização, } \\
\text { financiamento, planejamento, } \\
\text { Programação Pactuada e Integrada (PPI), } \\
\text { regulação, partici pação e controle social, } \\
\text { gestão do trabalho e educação na saúde. }\end{array}$ & $\begin{array}{l}\text { Processo de discussão de cerca } \\
\text { de dois anos, envolvendo os } \\
\text { técnicos e a direção das } \\
\text { diversas áreas do M inistério da } \\
\text { Saúde, do Conselho Nacional } \\
\text { de Secretários M unicipais de } \\
\text { Saúde - CONASEM S e do } \\
\text { Conselho Nacional de } \\
\text { Secretários de Saúde - } \\
\text { CONASS. O documento final } \\
\text { foi aprovado na Comissão } \\
\text { Intergestores Tripartite e no } \\
\text { Conselho Nacional de Saúde. }\end{array}$ \\
\hline $\begin{array}{l}\text { PPA } \\
\text { 2008-2011 } \\
\text { Desenvolvimento } \\
\text { com inclusão } \\
\text { social e } \\
\text { educação de } \\
\text { qualidade }\end{array}$ & $\begin{array}{l}\text { Acelerar o crescimento } \\
\text { econômico, promover a } \\
\text { inclusão social e reduzir as } \\
\text { desigualdades regionais; } \\
\text { Três agendas prioritárias: o } \\
\text { Programa de Aceleração do } \\
\text { Crescimento (PAC), o Plano } \\
\text { de Desenvolvimento da } \\
\text { Educação (PDE) e a Agenda } \\
\text { Social. }\end{array}$ & $\begin{array}{l}\text { Para viabilizar a estratégia de } \\
\text { desenvolvimento, prioriza: } \\
\text { - as políticas públicas voltadas para o } \\
\text { crescimento e a promoção da distribuição } \\
\text { de renda; } \\
\text { - a elevação da qualidade da educação; } \\
\text { - o aumento da produtividade e da } \\
\text { competitividade; } \\
\text { - a expansão do mercado de consumo de } \\
\text { massa; } \\
\text { - a utilização da diversidade dos recursos } \\
\text { naturais de forma sustentável; } \\
\text { - a melhoria da infraestrutura, inclusive } \\
\text { urbana (e regiões metropolitanas); } \\
\text { - a redução das desigualdades regionais; } \\
\text { - a segurança e o fortalecimento da } \\
\text { democracia e da cidadania. } \\
\text { Orientação política para a saúde } \\
\text { D esenvolver as políticas setoriais de saúde } \\
\text { e também buscar o esforço coordenado de } \\
\text { vários órgãos governamentais e da } \\
\text { sociedade para garantia da saúde- políticas } \\
\text { de inclusão social, de educação, de } \\
\text { segurança no trabalho, de esportes e } \\
\text { cultura, de segurança pública, de } \\
\text { organização do espaço urbano, de trânsito } \\
\text { e transporte. }\end{array}$ & $\begin{array}{l}\text { O processo contou com a } \\
\text { participação de segmentos } \\
\text { representativos da sociedade } \\
\text { em quarenta conferências } \\
\text { sobre diversas políticas } \\
\text { públicas, numerosos fóruns e } \\
\text { conselhos. }\end{array}$ \\
\hline
\end{tabular}

No caso da saúde, a trajetória fragmentada da política não possibilitava o planejamento nacional integrado. Com a instituição do Sistema
Ú nico de Saúde em 1988, previa-se um fortalecimento do planejamento público que foi, no entanto, prejudicado pelo contexto de reformas do 


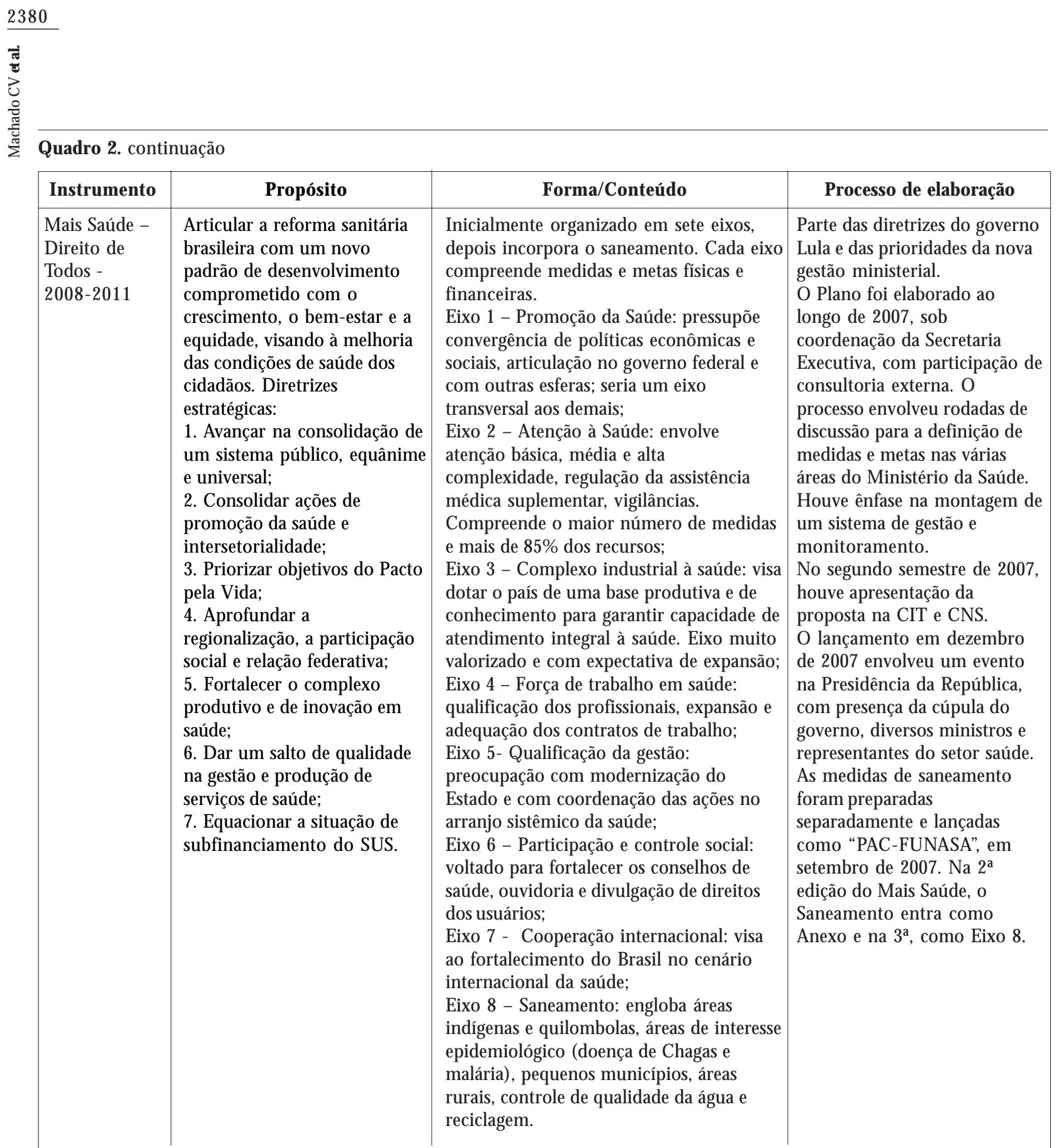

Fonte: Elaboração dos autores a partir dos documentos oficiais.

Estado dos anos noventa. Somente ao final daquela década, houve uma retomada de estratégias mais consistentes de planejamento estatal, com iniciativas também na saúde.

No período correspondenteao Governo Lula (2003 a 2010), há uma valorização do planejamento estatal, que parece influenciar positivamente as iniciativas setoriais de planejamento. Ressalte-se o desafio de fortalecer o planejamento nacional em um contexto democrático efederativo, o que implica debates eformação de consensos entre grupos sociais e esferas de governo.
As estratégias de planejamento adotadas pelo Ministério da Saúde no período refletiram elementos do contexto geral (a lógica do planejamento estatal no país, a conjuntura do governo Lula) e as peculiaridades da saúde (a especificidade do campo, a trajetória da política, o modus operandi do M inistério ea orientação política das gestões ministeriais).

Observa-se um adensamento das estratégias e instrumentos de planejamento nacional em saúde, como uma tentativa de dar direcionalidadeà política. O M inistério da Saúde procurou fortalecer o 
seu papel por meio do planejamento, compre endido como um processo técnico-político e social, que requer o envolvimento de vários atores.

Ademais, foram identificados dois momentos no que concerne ao planejamento federal em saúde. 0 planejamento em saúde no primeiro governo (2003 a 2006) é marcado por uma orientação democrática e gerencialista, envolven do ao mesmo tempo um intenso processo de debate interno ao Ministério e com outros atores (do governo federal, de outras esferas de governo) e o esforço de tradução das prioridades políticas em metas objetivas. No período correspondente ao segundo governo (2007-2010), a orientação gerencialista se mantém e observa-se um movimento setorial de atrelar a política de saúde ao debate do modelo de desenvolvimento, com re percussões incertas. Por outro lado, o processo de planejamento não expressa tão fortemente a adoção de mecanismos participativos amplos, marcante no período anterior.

Em que pesem os avanços observados, o planejamento em saúde no período expressa fragilidades. Algumas delas se relacionam à complexidade do campo e da condução nacional de uma política de implementação descentralizada: as limitações na realização de uma adequada análise situacional, a escassez de mecanismos de coordenação, diante de uma grande variedade de ações emetas, as dificuldades na definição deatribuições positivas para o gestor federal e os conflitos federativos relacionados à centralizaçãodescentralização.

Porém, as maiores fragilidades remetem a fatores de ordem geral, que sinalizam um lugar modesto da política de saúde no modelo de desenvolvimento. Um deles é a não regulamentação do financiamento da saúde, que tem comprometido as propostas delineadas nos instrumentos setoriais de planejamento. Outro é o caráter delimitado das prioridades governamentais para o setor e o pouco enfrentamento de problemas estruturais do sistema de saúde, como as distorções nas relações público-privadas e as imensas desigual dades em saúde.

Por fim, ressalte-se a fragilidade da lógica territorial no planejamento em saúde, querefleteum fenômeno mais geral de limitada apropriação da dimensão territorial no planejamento nacional. É premente a retomada da abordagem territorial com vistas à formulação de políticas diferenciadas segundo necessidades regionais e a realização de investimentos para a redução das desigualdades em saúde. Em um país imenso, heterogêneo e desigual, essas são questões críticas a serem enfrentadas para que o planejamento seja uma prática transformadora da realidade social.

\section{Colaboradores}

CV M achado, TW Baptista e LD Lima foram responsáveis pela concepção, desenvolvimento, redação e revisão do artigo.

\section{Agradecimentos}

0 desenvolvimento da pesquisa foi favorecido pelo apoio financeiro do Conselho Nacional de Desenvolvimento Científico e Tecnológico (CN Pq), da Fundação Carlos Chagas de Amparo à Pesquisa do Estado do Rio de Janeiro (FAPERJ) edo Programa Estratégico de Apoio à Pesquisa em Saúde da Fundação O swal do Cruz (PAPES-FIOCRUZ).

\section{Referências}

1. Instituto Latinoamericano de Planificación Economica y Social. Debates sobre Planejamento. Rio de Janeiro: Forum/H achette; 1974.

2. Rivera FJU, Matus C, Testa M, organizadores. Planejamento e programação em saúde: um enfoque estratégico. São Paulo: Cortez; Rio de Janeiro: Abrasco; 1989.

3. Evans P. O Estado como problema e solução. Lua N ova 1993; 28/29:107-156.

4. Fiori JL. O poder global e a nova geopolítica das nações. São Paulo: Boitempo; 2007.

5. Lenhardt G, Offe C. Teoria do Estado e política social. In: Offe $\mathrm{C}$, organizador. Problemas estruturais do estado capitalista. Rio de Janeiro: Tempo Brasileiro; 1984. p.10-53.

6. Thelen K, Steinmo S, editors. Structuring Politics. $\mathrm{H}$ istorical Institucionalism in Comparative Analysis. Cambridge: Cambridge University Press; 1992. 
7. Pierson P. Politics in time. Princeton: Princeton University Press; 2004.

8. Fonseca PCD. Gênese e precursores do desenvolvimentismo no Brasil. Pesquisa \& Debate 2004; 15(26):225-256.

9. Bielschowsky RA. Pensamento econômico brasileiro: o ciclo ideológico do desenvolvimentismo. Rio de Janeiro: Contraponto; 2004.

10. Arias N eto JM. Primeira República: economia cafeeira, urbanização e industrialização. In: Ferreira J, Delgado LAN, organizadores. 0 Brasil Republicano. 1: 0 tempo do liberalismo excludente. Rio de Janeiro: Civilização Brasileira; 2003. p.191-229.

11. Lima NT, Fonseca CM O, Hochman G. A saúde na construção do Estado Nacional no Brasil: reforma sanitária em perspectiva histórica. In: Lima NT, Gershman S, Edler FC, organizadores. Saúde e de mocracia: história e perspectivas do SUS. Rio de Janeiro: Fiocruz; 2005. p. 27-58.

12. Warhlich B. Reforma administrativa na Era Vargas Rio de Janeiro: FGV; 1983.

13. Nunes E. A gramática política do Brasil. Rio de Janeiro: Jorge Zahar; 1997

14. Draibe SM. O Welfare State no Brasil: características e perspectivas. [site da Internet] [acessado 2010 jan]. Disponível em: http://www.nepp.unicamp.br/ index. php? $\mathrm{p}=82$

15. Hamilton W, Fonseca C. Política, atores e interesses no processo de mudança institucional: a criação do Ministério da Saúde em 1953. Hist. cienc. saude-M anguinhos 2003; 10(3):791-825.

16. Brasil. Ministério da Saúde. Relatório da Terceira Conferência Nacional de Saúde. Brasília: Ministério da Saúde; 1986.

17. Souza AR. As trajetórias do planejamento governamental no Brasil: meio século de experiências na administração pública. Rev Serv Publico 2004 , 55(4):5-28

18. Araújo MC, Castro C, organizadores. Tempos modernos. João Paulo dos Reis Velloso: memórias do desenvolvimento. Rio de Janeiro: FGV; 2004.

19. Pena MVJ. Saúde nos Planos Nacionais de Desenvolvimento. Dados 1977; 16:69-96.

20. Sallum Jr. B. Crise, democratização e liberalização no Brasil. In: Sallum Jr. B, organizador. Brasil e Argentina hoje: política e economia. Bauru: EDUSC; 2004. p. 47-77.

21. Vaz JC. O monitoramento do planejamento governamental em ambientes complexos. In: Reppeto $\mathrm{F}$, organizador. Reflexões para a Ibero-América - Planejamento Estratégico. Brasília: ENAP; 2009. p. 37-44.

22. Boschi R, Lima MRS. O Executivo e a construção do Estado no Brasil. In: Vianna, LW, organizador. A democracia e os três poderes no Brasil. Belo Horizonte: UFMG; Rio de Janeiro: IUPERJ/FAPERJ; 2003. p.195-253.

23. Machado CV. $O$ modelo de intervenção do M inistério da Saúde nos anos 90. Cad Saude Publica 2007 23(9):2113-2126

24. Boschi R. Capacidades estatais e políticas de desenvolvimento no Brasil. In: M elo CR, Sáez MA organizadores. A democracia brasileira. Belo Horizonte: Editora UFM G; 2007. p. 303-326.

25. Kliass P. 0 início do Segundo Mandato de Lula e o Plano de Aceleração do Crescimento. Lusotopie 2007; XIV (2):157-168.
26. Costa NR. A proteção social no Brasil: universalismo e focalização nos governos FHC e Lula. Cien Saude Colet 2009; 14(3):693-706.

27. Vianna M LW. As batatas de Pirro. Comentários sobre As regras institucionais, constrangimentos macroeconômicos e inovação do sistema de proteção social brasileiro nas décadas de 1990 e 2000. Cien Saude Colet 2009; 14(3):707-719.

28. Viana $A L$, Lima LD, organizadores. Regionalização e Relações Federativas na Política de Saúde do Brasil. No prelo 2010.

29. Toni J. Alta direção e planejamento estratégico: o funcionamento do gabinete presidencial como teto à capacidade para governar. [site da Internet] [acessado 2010 mar 14]. Disponível em: http://www.espacoacademico. com.br/044/44ctoni.htm

30. Moraes MVE, Silva TF, Costa PV. O mito do inchaço da força de trabalho do executivo federal. Res Pvblica 2009; 7(2):1-17.

31. Brasil. M inistério do Planejamento, Orçamento e Gestão. Plano Plurianual 2004-2007: M ensagem Presidencial. Brasília: Ministério do Planejamento, Orçamento e Gestão; 2003.

32. Fiori JL. Notas para um debate democrático sobre 0 "Plano Plurianual 2004-2007". Proposta 2003; 97:6-11.

33. Brasil. Portaria $\mathrm{n} 02.607 / \mathrm{GM}$ de 10 de dezembro de 2004. Aprova o Plano Nacional de Saúde/PNS U m Pacto pela Saúde no Brasil. Diário Oficial da União 2004; 13 dez.

34. Brasil. Portaria GM /M S no 399 de 22 de fevereiro de 2006. Divulga o Pacto pela Saúde 2006 - Consolidação do SUS e aprova as Diretrizes Operacionais do Referido Pacto. Diário Oficial da União 2006; 23 fev.

35. Viana ALD, Ibañez N, Elias PEM, Lima LD, Albuquerque $M$, Iozzi $F L$. Novas perspectivas para a regionalização da saúde. São Paulo Perspec 2008; 22(1):92-106

36. M attos RA, Robaina JR, Siqueira NN. Planejamento, avaliação e pactuação: algumas reflexões sobre o processo de pactuação a partir do Pacto dos Indicadores da Atenção Básica. In: Pinheiro R, Silva Jr. AG, Mattos RA, organizadores. Atenção básica e integralidade. Rio de Janeiro: CEPESC/IM S-UERJ/ Abrasco; 2008. p. 295-312.

37. Brasil. Ministério do Planejamento, Orçamento e Gestão. Plano plurianual 2008-2011: projeto de lei. Brasília: Ministério do Planejamento, Orçamento e Gestão; 2007.

38. Brasil. Ministério da Saúde. Mais Saúde - Direito de Todos: 2008-2011. 2ª ed. Brasília: M inistério da Saúde; 2008.

39. Brasil. M inistério da Saúde. Mais Saúde - Direito de Todos: 2008-2011. 3a ed. Brasília: M inistério da Saúde; 2009.

Artigo apresentado em 29/04/2010

Aprovado em 30/05/2010

Versão final apresentada em 01/06/2010 